\title{
A Review on Artificial Recharge Schemes in Chandigarh City
}

\author{
Lokmitra Meshram $^{1}$, Dr. Sanjay Kumar Sharma ${ }^{2}$, Dr. Dwarikanath Ratha ${ }^{3}$ \\ ${ }^{1}$ Research Scholar, ${ }^{2}$ Professor and Head, Civil Engineering Department, NITTTR, Chandigarh, \\ ${ }^{3}$ Associate Professor, Thapar University, Patiala
}

DOI: 10.46335/IJIES.2020.5.8.2

\begin{abstract}
Chandigarh city was designed by the renowned French architect Le Corbusier and. it was attractively situated at the Shivaliks foothills. The need of artificial recharge of aquifers is expanding step by step inordinate interest of water by the ever-developing populace and furthermore shortage of better dam locales accessible used for development. Artificial water recharge is the way toward adding up water throughout human exertion. A essential goal of artificial water recharge system is towards safeguard or upgrade groundwater assets in different pieces of India which incorporates removal or preservation floodwaters, controlling of saltwater interruption, stockpiling of water for lessening the costs of siphoning and funneling, transitory guideline of groundwater deliberations, and improvement in water quality by weakening by blending in with normally happening ground water. The target of this review is to introduce a survey of artificial water revive framework in the NITTTR Campus - Chandigarh City. Also, climate and rainfall, soil types and geomorphology, scenario of ground water, management strategy for ground water, problems and issues related to ground water discussed in details.
\end{abstract}

\section{I- INTRODUCTION}

C handigarh, the nightmare city of India's first Prime Minister, Shri Jawahar Lal Nehru, was arranged by the well-known French planner Le Corbusier. Beautifully situated at the lower regions of Shivaliks. It is situated around $250 \mathrm{kms}$. north of New Delhi. At the hour of rearrangement of the state in 1966 into Punajb, Haryana and Himachal Pradesh, the city expected the exceptional differentiation of being the capital city of both, Punjab and Haryana States while it itself was pronounced as a Union Territory and under the immediate control of Central Government and it doesn't frame some portion of any of the two States. It lies between north scopes $30^{\circ}$ $40^{\prime}$ and $30^{\circ} 46^{\prime}$ and east longitudes $76^{\circ} 42^{\prime}$ and $76^{\circ} 51^{\prime}$. Chandigarh has a region of 114 sq.km., out of which 34 sq. $\mathrm{km}$. is country and staying $80 \mathrm{Sq} . \mathrm{km}$, is urban. The city is isolated into 55 dwelling segments. According to evaluation 2011, all out populace of the city was $1,054,686$ people having a populace thickness of 9252 people/sq.km. The elevation of the city ranges from 304 to 365 meters above MSL

Owing to environmental change, fast urbanization as well as populace development, required water deliver expanding fluctuations [1-2]. For illustration, in dry or semi-dry areas, outside water is confronting consumption nearby groundwater that is in excess abused because of enlarged generalization [3-4]. The capacity of surface water reservoirs is far reaching however it has some disadvantages which incorporates high vanishing misfortunes, huge land region necessities, residue gathering, the chance of breakdown structure and high powerlessness to defilement [5-6]. An option in contrast near the outside storage is to hoard overabundance water underground through times of small interest or elevated accessibility [7]. Artificial 
recharge is done for soon healing otherwise ecological advantages represents a significant technique used for economical water resources management [8-9]. In contrast to different kinds of assets the executives techniques, vital advantages of artificial recharge maintain advanced water demands, overcome the secular difference between supply water and require, water quality development, along with the safety of water against departure losses, green growth sprouts, and air aftermath of poisons during underground stockpiling [10]. In artificial water recharge, the ground water has been impressively intensified by removing the saltiness, therefore recovering an amount of water and the nature.
The artificial recharge techniques are ending up being viable in upkeep and renewal of the aquifers [11]. The ground water recharge can be happens artificially as well as naturally. The normal recharge happens by process of invasion in which water permeates. Be that as it may, because of fast turn of events and marvelous development of populace in the ongoing past the regions for regular penetration which have been diminishing step by step, consequently the possibility for naturally recharging of a ground water is additionally failing. Therefore anthropological techniques have been executed for enhancement of infiltration process [12].

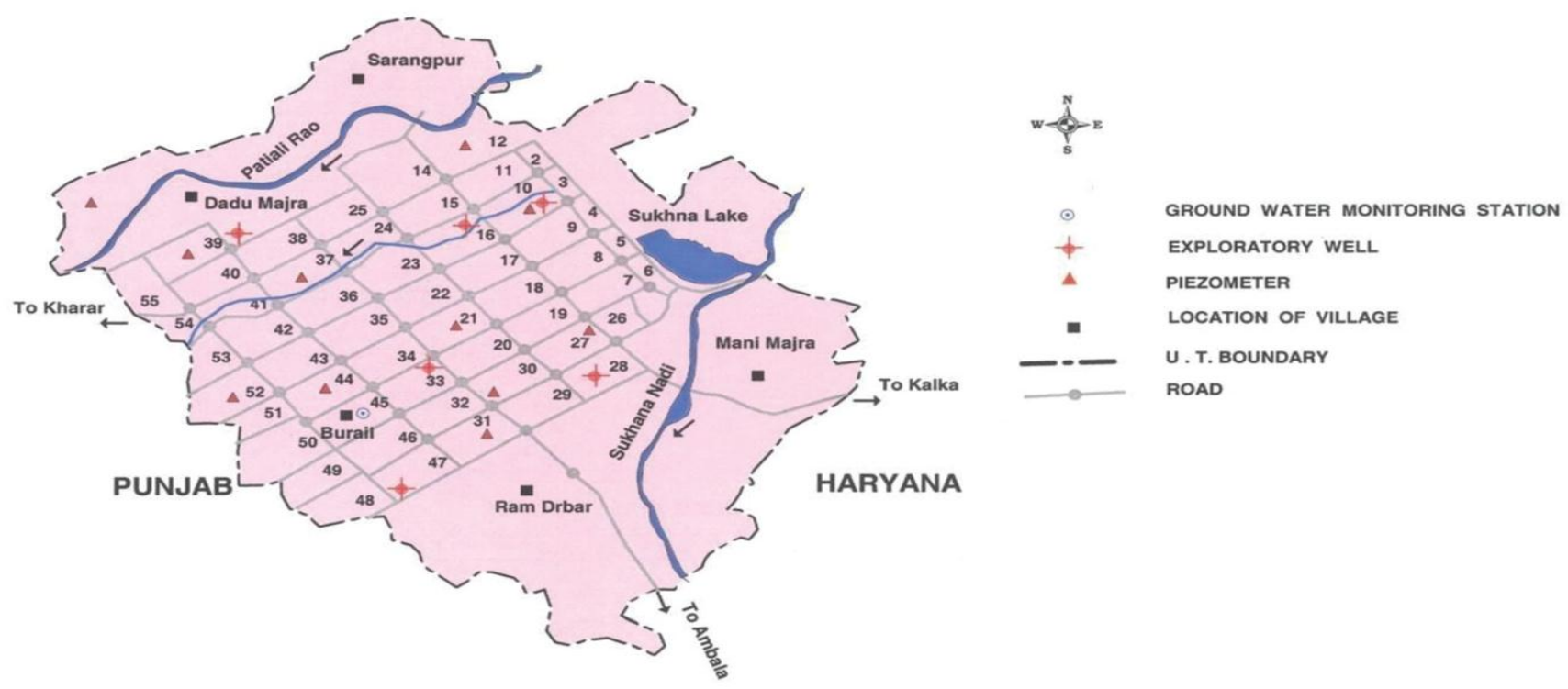

Fig 1- Map of Chandigarh [13].

Because of high urbanization, practically $77.94 \%$ of the complete territory isn't accessible for development. The net region planted is 11.12 sq. km. furthermore, the current neglected is 0.49 sq.km. Territory under timberland is 2.12 sq.km. Primary yields developed during Kharif are rice, maize, potato and sugar stick while during Rabi season wheat, gram and oil seeds are developed. There are no enormous common surface water bodies in Chandigarh however little lakes do exist in the country regions [14-16]. The Sukhna Choe has been dammed in eastnorth side of the city, which has offered artificial lake covering a region of about 1.62 sq.km. The lake, known as Sukhna has a water holding limit of 5,000,000 cubic meters (MCM).

UT of Chandigarh falls in the Ghaggar Basin. There are two significant streams, Sukhna Choe and Patiali ki Rao that begin from Siwalik Hills ranges and structures the common waste of the city. Six exploratory wells and eighteen piezometers have been penetrated by Central Ground Water Board in the UT Chandigarh for depiction spring geometry, nature of development water and hydrogeological investigation of the zone. The shallow and profound piezometers were were developed by the focal Ground Water Board for the investigation of water level conduct in Chandigarh and changes in the nature of ground water in existence.

\section{II- RAINFALL AND CLIMATE}

The atmosphere of Chandigarh can be delegated subtropical with sweltering summer and cold winter aside from during rainstorm season when damp quality of maritime cause arrives at the region [17-18]. There are four seasons in a year. The typical yearly precipitation of the UT is $1061 \mathrm{~mm}$, which is unevenly disseminated over the territory in 49 days. The southwest rainstorm sets in from week ago of June and pulls back in end of September, contributes about $80 \%$ of yearly 


\section{International Journal of Innovations in Engineering and Science, Vol 5, No.8, 2020}

\section{www.ijies.net}

precipitation. July and August are the wettest months. Rest $20 \%$ precipitation is gotten during non- rainstorm period in the wake of western unsettling influences and tempests. The summers and winters show extraordinary temperature mixed by monsoon. The Mean Maximum temperature of the city is $39.1^{\circ} \mathrm{C}$ (May and June) and the mean Minimum is $6.1^{\circ} \mathrm{C}$ (January). The most noteworthy recorded temperature in Chandigarh was $46.5^{\circ} \mathrm{C}$ on 20 June, 1964 and the minimum was $(-) 1.2^{\circ}$ $\mathrm{C}$ on 26 January, 1964. The relative stickiness contacts $80 \%$ during July - August while the least relative moistness estimations of $26 \%$ are recorded during April-May. Wind speed is most extreme at $8.4 \mathrm{~km} / \mathrm{hr}$ during May while it is least at $3.2 \mathrm{~km} /$ hour during September. The normal yearly dissipation for Chandigarh works is $2110 \mathrm{~mm}$. The most reduced month to month dissipation is $7.2 \mathrm{~mm}$ during January and most noteworthy of $36.3 \mathrm{~mm}$ happens in May.

Rainfall : Average Rainfall (Annual) : $1061 \mathrm{~mm}$; Average Rainfall (Monsoon) : $849 \mathrm{~mm}$

Average Rainy days : 49

Temperature: Mean Minimum: $6.1^{\circ} \mathrm{C}$ (January); Mean Maximum: $39 \cdot 1^{\circ} \mathrm{C}$ (May \& June).

Figure 2 shows the rainfall data of the last 5 years of Chandigarh.

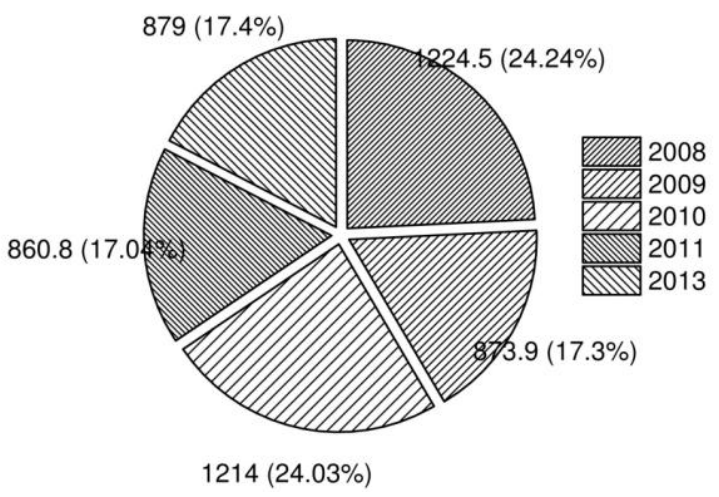

Fig 2-Rainfall data of the last 5 years of Chandigarh [13]

\section{III- SOIL TYPES}

The soils in UT Chandigarh are loamy sand at surface and calcareous sandy soil in subsurface layers [19-20]. The hard earth structures container at profundities changing somewhere in the range of 20 and $30 \mathrm{~m}$..

In northern parts the soil is sandy to sandy soil where as it is loamy to residue topsoil in southern parts. The soils in Chandigarh are light yellowish earthy colored to pale earthy colored in shading. Practically all the soils are inadequate in nitrogen, phosphorous and potash.
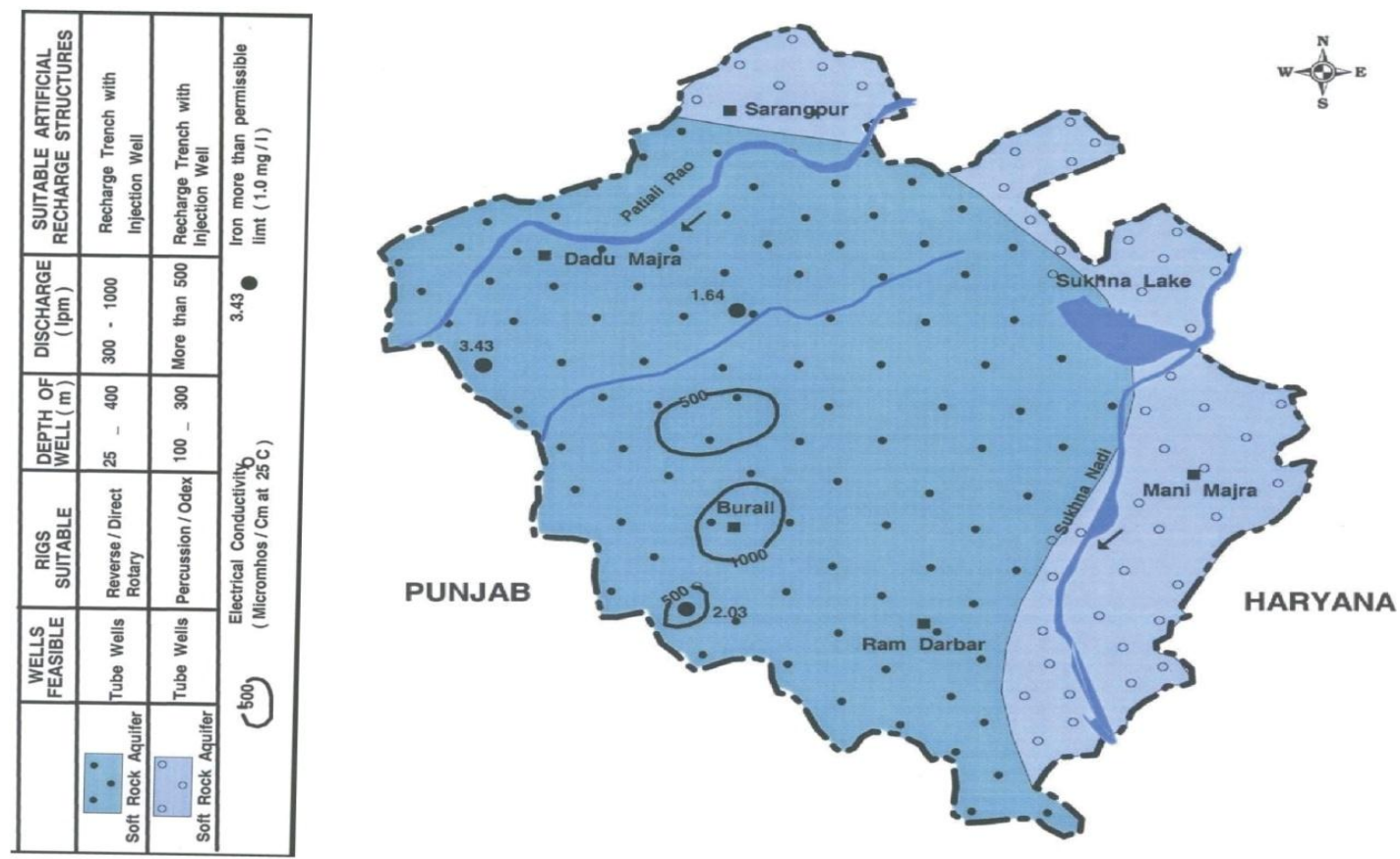

Fig 3- Hydrogeology of Chandigarh [13] 


\subsection{Hydrogeology}

The Union Territory of Chandigarh is involved by semi combined arrangements of upper Siwalik arrangement of center Miocene age that are uncovered in north eastern periphery though the remainder of the Territory is involved by Indo-Gangetic plain including alluvium of Pleistocene age. The piedmont stores at the foot of Siwalik Hills involve cobble, stone and rock, related with sand, sediment and dirt. The piedmont stores are trailed by alluvial plain contained mud, sediment and sand.

The arrangements have been saved by the drainage framework beginning in the Siwaliks. Coarser residue happen along the Sukhna Choe and Patiali ki Rao while generally better dregs, therefore limiting the aquifer disposition horizontally, underlie the zone between these two streams.

The arrangements experienced in a borehole penetrated down to $465 \mathrm{mbgl}$ in segment 28, near Sukhna Choe, are all around characterized coarse dregs up to $240 \mathrm{mbgl}$. Beneath this profundity the developments are better grained. This shows the thickness of coarser dregs is more prominent in northern pieces of the city when contrasted with the southern parts.

Along Sukhna Choe, three conspicuous sand beds happen (inter-bedded with clay beds) inside a profundity of around $100 \mathrm{~m}$. The upper sand beds are around $15 \mathrm{~m}$ thick and happen $8 \mathrm{~m}$ underneath land surface. Center sand bed is around $18 \mathrm{~m}$ thick and happens at profundities differing from 21 to $38 \mathrm{mbgl}$. The more profound sand bed happens at profundity fluctuating from 39 to $76 \mathrm{mbgl}$ and is around $27 \mathrm{~m}$ thick.

Along the Patiali-ki-Rao nala a solitary thick sand bed has been watched. This thick bed is between layered

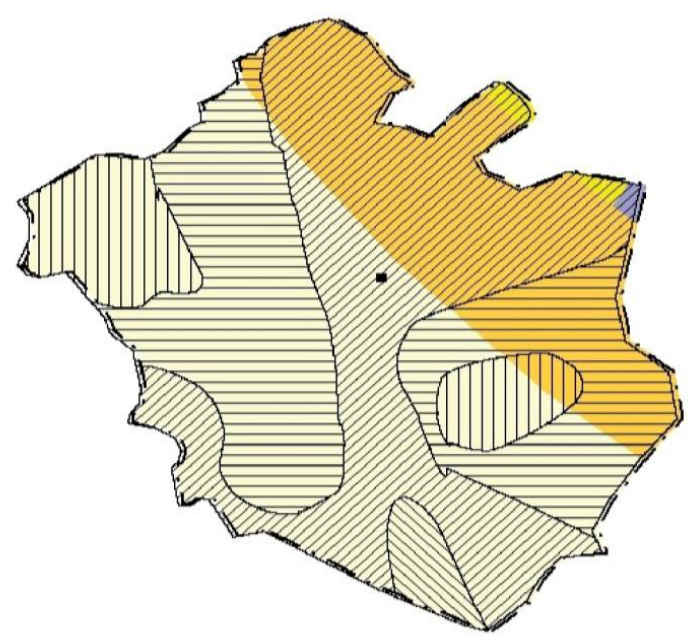

with earth focal points in east north and westsouth directions of the nala. This bed proceeds yet diminishes towards southeast. Further this bed gets split up into two units isolated by $20-25 \mathrm{~m}$ thick earth beds.

Ground water in the zone happens submerged table, restricted just as semi-bound conditions [21-23]. The siphoning test information of the aquifers tried in the city unmistakably demonstrates that great restricted springs happen around division 10,33, 38 and 47 while broken are experienced around part 28 . The depth of the shallow aquifer framework is under $30 \mathrm{~m}$ below ground level though the depth of the deeper aquifer system ranges from 40 to $450 \mathrm{mbgl}$ of investigated depth while in Manimajra territory limited aquifers happen under $90 \mathrm{~m}$.

Various aquifer execution tests were likewise directed on the current shallow tubewells and just the recuperation information was utilized to survey the aquifer boundaries. The transmissivity estimations of shallow aquifers up to $100 \mathrm{~m}$ depth extend got during these tests went somewhere in the range of 70 and $466 \mathrm{~m} 2 /$ day. Water table rise study uncovers that the progression of ground water is from north to westsouth and southern directions. Water table rise contrast among northern and southwestern parts is $20 \mathrm{~m}$ and lies between $330 \mathrm{~m}$ amsl and $310 \mathrm{~m}$ amsl.

During the pre-rainstorm period depth to water level in the shallow aquifer system differs between 1.22 in the southern parts to $45 \mathrm{mbgl}$ in the northern zones. In the western and south-western piece of the city covering parts 39 to 47 the water level is shallow - under five meters. This is because of better nature of silt and lithological limits. In the territory falling north of Madhya Marg, it shifts from $16 \mathrm{~m}$ to $27 \mathrm{~m}$ below ground level. Anyway in Manimajra territory it is most extreme in the scope of $70-80 \mathrm{mbgl}$.

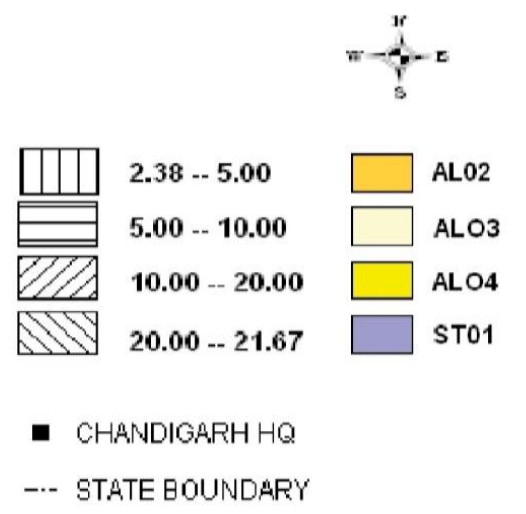

Fig 4- Depth to water level post monsoon 2011 of Chandigarh [13] 
The occasional (Pre-post rainstorm) water level fluctuation in the shallow aquifer isn't huge. A larger piece of the city has indicated an rise in water levels, the most extreme being $6.09 \mathrm{~m}$ meters in segment 12 and 0.14 meters at Maloya. The western side of the city has enrolled a decrease, the most extreme being 1.1 meters at Maloya.

The drawn out water level fluctuation information of the shallow aquifer system uncovers there is a general decrease of water levels going between $-0.43 \mathrm{~m}$ at area 37 and $-7.19 \mathrm{~m}$ at part 12 while the ascent of $0.04 \mathrm{~m}$ at Maloya and $2.92 \mathrm{~m}$ at segment 52 is watched.

\subsection{Quality of Ground Water}

In light of the information created from the investigation of ground water tests drawn from hand pump and cylinder wells, it is discovered that the ground water is new and reasonable for drinking just as water system purposes. The conductivity esteems are under 1000 small scale Siemens for every $\mathrm{cm}$ aside from in shallow spring at Burail where conductivity is 1030 smaller scale Siemens for every $\mathrm{cm}$. Convergence of a portion of the imperative quality markers, for example, F, NO3, saltiness, and hardness is inside reasonable constraints of drinking water measures (BIS - 1991). Among anions, bicarbonate is the prevailing anion. None of the ground water tests from more deeper zone demonstrated centralization of these constituents above greatest allowable level.

To assess water system reasonableness of ground waters, plot of SAR and EC on a broadly utilized USSL chart uncovered that lion's share of the waters fall under C1S1, $\mathrm{C} 2 \mathrm{~S} 1$ and $\mathrm{C} 3 \mathrm{~S} 1$ classes of water system rating. Utilization of such waters for water system may cause medium saltiness risks to salt touchy harvests and low sodium danger on soil with low porousness. Nonetheless, these waters are suitable for customary irrigation to salt tolerant crops grown on soils of medium permeability.

\subsection{Ground Water Resources}

Ground Water Resources of Chandigarh have been evaluated for the water table aquifer as on 31.03.2011 by considering the accompanying information into thought:

The all out geological region of Chandigarh is 114 Sq.km. what's more, depth to water level in shallow aqifers extended from $4.48 \mathrm{~m}$ to $8.47 \mathrm{~m}$ during Prerainstorm of 2006-2010 while it was 4.53 to $8.07 \mathrm{~m}$ during Post monsoon 2006-2010. Explicit yield in the zone of water table change was taken as $12 \%$ and Rainfall infiltration factor as $20 \%$ (according to standards) and there was no pumpage/ground water draft from shallow aquifers. There were 30 water system tubewells oversaw by Chandigarh Administration in the different towns of U.T., Chandigarh. The depth of these wells is in the scope of $180 \mathrm{~m}-250 \mathrm{~m}$. These tubewells tap bound springs under $78 \mathrm{~m}$ from ground level. There were 239 tubewells for drinking water flexibly to the rural and urban populace. These tubewells tap restricted springs under $90 \mathrm{~m}$ from ground level. The depth of these wells ranges from 200-300 m.

\subsection{Status of Ground Water Development}

As Per the examinations completed by CGWB in Chandigarh, three aquifer groups have been recognized. Aquifer Group - I happens fundamentally in the northern pieces of the city. It involves slight sand and rock beds of changing thickness. This gathering happens mainly in the depth range of 325 to $315 \mathrm{~m}$ amsl (above mean ocean level). The release of tubewells developed in this gathering ranges somewhere in the range of 450 and $900 \mathrm{lpm}$. for drawdowns going somewhere in the range of 2.5 and 25 meters. Aquifer Group - II happens in the depth range of $290-250 \mathrm{~m}$ amsl. The release of tubewells developed in this gathering fluctuates from $650-1000 \mathrm{lpm}$. Because of fine nature of residue the drawdown is high. Aquifer Group - III is the last deepest aquifer group happening in the zone. The normal thickness is around $30 \mathrm{~m}$ in the region. It happens between $210-180 \mathrm{~m}$ amsl. The thickness of individual confined aquifer is 10 to $30 \mathrm{~m}$ and sand is medium to coarse grained. The water bearing zones are highly potential and yield about $2000 \mathrm{lpm}$. 


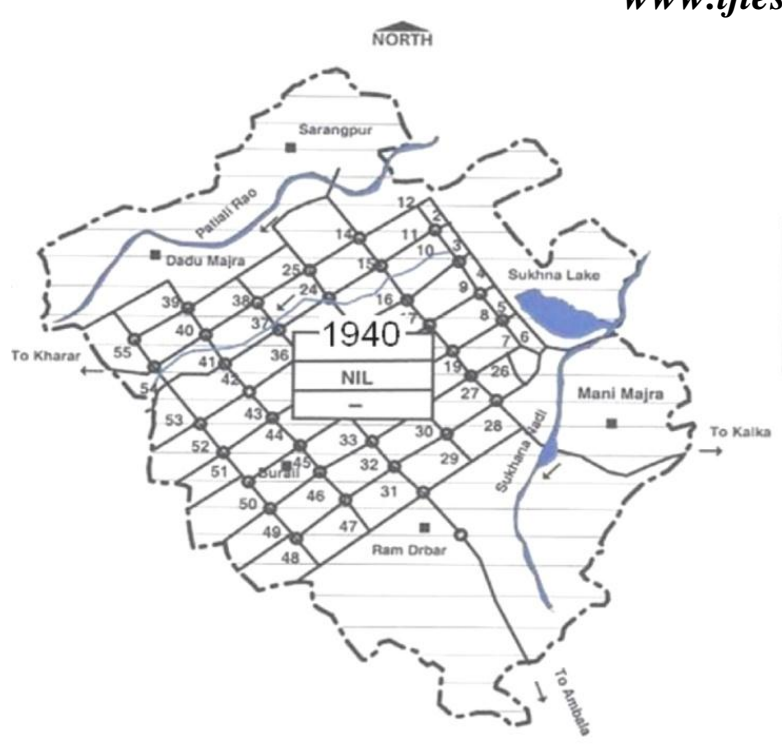

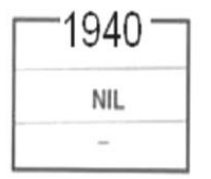

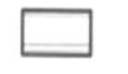

SAFE

Fig 5- Ground water development potential [13]

There are 200 deep tubewells in the city, which contribute an aggregate of 91 MLD (20 MGD) of water from ground water saves for drinking water supplies to the urban zones of the city. Other than there are 39 tubewells, which give drinking water to country region additionally separated 30 tube wells for irrigation.

\section{V-GROUND WATER MANAGEMENT STRATEGY}

\subsection{Ground Water Development}

According to the Water Supply Bye Laws of Chandigarh just the more deep aquifers, under $100 \mathrm{~m}$, are to be misused in Chandigarh city. There are 200 deep tubewells in urban regions and 39 tubewells in country zones for drinking purposes. For water system, there are 30 government tubewells in the country zones. Because of event of stones at different depths in the northern and eastern parts, the penetrating must be embraced by percussion or DTH-cum-Odex strategy. In the boreholes penetrated in the stone arrangements, tapping around 30 $\mathrm{m}$ of spring thickness through an opened admission partition having a space size in the scope of 1.5-3.0 mm is generally reasonable and is probably going to yield around 750 to $1000 \mathrm{lpm}$ of good nature of ground water for moderate drawdowns. In the boreholes bored with revolving rigs, an admission part of $30 \mathrm{~m}$ through an opened channel of 1.0 to $1.5 \mathrm{~mm}$ space size would yield around 400 to $800 \mathrm{lpm}$ of ground water.

\subsection{Water Conservation and Artificial Recharge}

Chandigarh is a profoundly urbanized city and the roofetop of the structures can be reasonably utilized for artificial recharge of the rainfall falling in Chandigarh. Shallow aquifer happens under semi-limited conditions and exists down to 20 to $30 \mathrm{~m}$ underneath land surface. Deep aquifer under $40 \mathrm{~m}$ are under limited conditions. The piezometric top of the deep aquifer stands much underneath the water table of shallow aquifers and consequently it can get water effectively on being energized misleadingly. The tubewells in Chandigarh are tapping just the more depth aquifer system which causes fall in piezometric head of more profound aquifer system; whereas water level in the shallower aquifer system is rising. The profundity of the revive well is recommended to associate with $40 \mathrm{~m}$. The channel ought to be loaded up with the channel material The channel fills double need of putting away the abundance water and sifting the suspended particles/sediment. After development of channel cum revive well, the channelized water is to be associated with the energize structures through R.C.C. or then again M.S. pipes.

Central Ground Water Board, North-Western Region has taken up the accompanying artificial recharge projects in UT of Chandigarh under different midway helped plans. These projects were executed by different offices of Chandigarh Administration and Municipal Corporation.

\section{VI- GROUND WATER RELATED ISSUES AND PROBLEMS}

Luckily there are no large issues identified with ground water in the city aside from a decrease in the piezometric head of the deeper aquifers because of supported siphoning. As referenced before as well, the Water Supply Bye Laws of Chandigarh guarantee all the water 


\section{International Journal of Innovations in Engineering and Science, Vol 5, No.8, 2020 $w w w . i j i e s . n e t$}

flexibly is to be met from government tubewells and no private tubewells are permitted to be developed. Additionally just the deeper aquifer, under $100 \mathrm{~m}$, are being abused and in this way at present there is none or immaterial withdrawal of ground water from shallow aquifers in Chandigarh city.

This is additionally obvious from the way that though there is an overwhelming decrease in the water levels of the more deeper aquifers because of supported siphoning, there is not really any decrease in water levels of the shallow aquifers. The water levels are particularly very shallow in the southern divisions (and Mohali where in specific regions water logged conditions exist and dewatering must be depended on while developing multi-storeyed structures). It merits referencing that the chemical quantity of ground water of all the aquifer system in Chandigarh is acceptable and inside as far as possible recommended by BIS (1991) for drinking water aside from at several areas where water test drawn from hand pumps that are around $15 \mathrm{~m}$ depth, the iron focus was higher than as far as possible. This may likewise be because of corrosion in the delivery pipes.

\section{VII- CONCLUSIONS}

Chandigarh has a populace of 10.54 lakhs as on 2011, anyway the undertaking populace in 2021 would be 12.40 Lakhs (approx.). Presently, a significant piece of water prerequisite of the city is met by cannal water. Cannal water flexibly to the city is roughly 305 MLD (67 MGD). There are 200 deep tubewells in the city, which contribute an aggregate of 91 MLD (20 MGD) of water which have been saves from ground water. Other than there are 39 tubewells, that provide drinking to rural area too.

As of now referenced, Chandigarh city has the twin issue of ground water decrease just as rise. While the deeper aquifer are under extraordinary pressure and are portraying declining water levels, the shallow aquifers are not being put to any utilization and the water levels are rising and furthermore causing close to water logging conditions in the southern regions of the city. To adjust this issue, it is basic that siphoning from the deeper aquifer is diminished and that from the shallow aquifers be expanded. The misuse from the shallow aquifer ought to be gathered in the southern segments, particularly 39 to 55 in light of shallow ground water levels.

Artificial recharge of the deeper aquifer ought to be taken up to capture the decrease in the piezometric head. It ought to be made obligatory for all the buildings having a rooftop region of more than 250 sq. meters.

\section{REFERENCES}

[1] Pachauri, R.K., Allen, M., Barros,V., et al., 2014. Climate Change 2014: Synthesis Report. Contribution of Working Groups I, II and III to the Fifth Assessment Report of the Intergovernmental Panel on Climate Change.

[2] Gale, I., Dillon, P., 2005. Strategies for Managed Aquifer Recharge (MAR) in semi-arid areas, Paris: International Hydrological Programme (IHP).

[3] Wada, Y., Beek, L.P.H.V., Kempen, C.M.V., Reckman, J.W.T.M., Vasak, S., Bierkens, M.F.P. , 2010. Global depletion of groundwater resources. Geophysical Research Letters, 37(20).

[4] Gleeson, T., Wada, Y., Bierkens, M.F.P, van Beek, L.P.H, 2012. Water balance of global aquifers revealed by groundwater footprint. Nature 488, 197-200.

[5] Bouwer, H., 2002. Artificial recharge of groundwater: Hydrogeology and engineering. Hydrogeol. J. 10, 121142.

[6] Minsley, B.J., Ajo-Franklin, J., Mukhopadhyay A., Morgan, F.D. 2011. Hydrogeophysical Methods for Analyzing Aquifer Storage and Recovery Systems. Ground Water 49, 250-269.

[7] Händel, F., Liu, G., Dietrich, P., Liedl, R., Butler, J.J, 2014. Numerical assessment of ASR recharge using small-diameter wells and surface basins. J. Hydrol. 517, 54-63.

[8] Ringleb, J., Sallwey, J., Stefan, C., 2016. Assessment of Managed Aquifer Recharge through Modeling-A Review. Water, 8, 1-31.

[9] Dillon P., Pavelic P., Page D., Beringen H., Ward J., 2009. Managed aquifer recharge. In An introduction Waterlines Report Series No. 13. National Water Commission: Canberra, Australia.

[10] Hartog, N., Stuyfzand, P.J., 2017. Water Quality Considerations on the Rise as the Use of Managed Aquifer Recharge Systems Widens. Water 9, 808.

[11] Fred H.K Jr (2006) "Artificial Recharge of Aquifers". accessed online, 28th July at onlinelibrary.wiley.com/doi/10.1111/gwat.1963.1.issue1/issuetoc2-8-2010

[12] Waghmare S.N., Shelare S.D., Tembhurkar C.K., Jawalekar S.B. (2021), Development of a Model for the Number of Bends During Stirrup Making Process. In: Prakash C., Krolczyk G., Singh S., Pramanik A. (eds) 
International Journal of Innovations in Engineering and Science, Vol 5, No.8, 2020

\section{$w w w . i j i e s . n e t$}

Advances in Metrology and Measurement of Engineering

Surfaces. Lecture Notes in Mechanical Engineering. Springer, Singapore.

[13] Ground water information booklet, Central ground water board ministry of water resources, Government of India, Chandigarh, 2013.

[14] Jaafar, H.H. (2014): Feasibility of groundwater recharge dam projects in arid environments. Journal of Hydrology, 512 (1): 16-26.

[15] Waghmare S.N., Sakhale C.N., Tembhurkar C.K., Shelare S.D. (2020) Assessment of Average Resistive Torque for Human-Powered Stirrup Making Process. In: Iyer B., Deshpande P., Sharma S., Shiurkar U. (eds) Computing in Engineering and Technology. Advances in Intelligent Systems and Computing, vol 1025. Springer, Singapore.

[16] Shelare S.D., Kumar R., Khope P.B. (2021) Formulation of a Mathematical Model for Quantity of Deshelled Nut in Charoli Nut Deshelling Machine. In: Prakash C., Krolczyk G., Singh S., Pramanik A. (eds) Advances in Metrology and Measurement of Engineering Surfaces. Lecture Notes in Mechanical Engineering. Springer, Singapore

[17] Senent-Alonso, M. (1984): Problemática de la recarga artificial de acuíferos. Realizaciones españolas y sus posibilidades en el sureste español. Doctoral Thesis, Univ. Polytechnic of Madrid, 429 p.

[18] Martín-Rosales, W., Gisbert, J., Pulido-Bosch, A., Vallejos, A. and Fernández-Cortés, A. (2007): Estimating groundwater recharge induced by engineering systems in a semiarid area (southeastern Spain). Environmental Geology, 52 (5): 985-995.

[19] U.S. Environmental Protection Agency (EPA ), 2012. Guidelines for Water Reuse 2012, EPA/600/R-12/618. US Environmental Protection Agency and US Agency for International Development, Washington, DC, USA.

[20] Sahu P., Shelare S., Sakhale C. (2020), Smart Cities Waste Management And Disposal System By Smart System: A Review. International Journal of Scientific \& Technology Research Volume 9, Issue 03, March 2020. Pp 4467-4470.

[21] Jawalekar, S. B., and S. D. Shelare. 2020. Development and performance analysis of low cost combined harvester for rabicrops. Agricultural Engineering International:CIGR Journal, 22 (1):197-201.
[22] Wiese, B., Massmann, G., Jekel, M., Heberer, T., Dünnbier, U., Orlikowski, D., Grützmacher, G., 2011. Removal Kinetics of Organic Compounds and Sum Parameters under Field Conditions for Managed Aquifer Recharge. Water Research 45, 4939-4950.

[23] Shan, B., Zheng, X., Qiao, Z., Lan, X., 2013. Experimental study of aquifer physical clogging during artificial recharge process. Periodical of Ocean University of China 43, 97-101. 